\title{
The Effect of Supportive Leadership, Learning Culture, and Responsibility on Job Performance of Teacher in Junior High Schools of South Tangerang
}

\author{
Sahat T. Simorangkir $1, a^{*}$, Neti Karnati $11, b$, Thamrin Abdullah ${ }^{1, c}$ \\ 1Department of Education Management, Universitas Negeri Jakarta, Jakarta Timur, 13220, Indonesia \\ a sahatts@yahoo.co.id; b neti.karnati@unj.ac.id; c thamrin.abdullah@yahoo.co.id \\ ${ }^{*}$ Corresponding Author
}

How to Cite : Simorangkir, S., T., Karnati, N., \& Abdullah, T., (2019). The Effect of Supportive Leadership, Learning Culture, and Responsibility on Job Performance of Teacher in Junior High Schools of South Tangerang. International Journal for Educational and Vocational Studies, 1 (2), 120-129

\section{ARTICLE HISTORY}

Received:12 April 2019

Revised: 20 May2019

Accepted: 28 May 2019

\section{KEYWORDS}

Job performance;

Supportive Leadership;

Learning Culture and Responsibility

\begin{abstract}
The objective of this research was to determine the effect of supportive leadership, learning culture, and responsibility to job job performance of teacher's in South Tangerang. The research was conducted by using a survey method with path analysis applied on testing hypothesis. The target population size of this research is 454 of teachers. Research samples selected as much as 213 teachers using simple random sampling technique. Based on this research of data obtained the following conclusions: (1) the supportive leadership has positive direct effect to job job performance, (2) the learning culture as positive direct effect to job job performance, (3) responsibility has positive direct effect to job job performance, (4) the supportive leadership has positive direct effect to responsibility,(5) learning culture have positive direct effect to responsibility, (6) the supportive leadership has positive direct effect to learning culture. The conclusion is that the teacher's job job performance is effected by the supportive leadership, learning culture, and teacher's responsibility.
\end{abstract}

This is an open access article under the CC-BY-SA license.

\section{INTRODUCTION}

The role of the teacher is believed to be replaced by any sophisticated machine. Because teachers are needed to shape the character of the nation's children with character, tolerance, and good values. Teachers are also able to foster social empathy, build imagination and creativity, and strengthen the spirit of national unity and unity. Evaluating the productivity of school teachers has become a focal point in the latest policy efforts to improve the education system in schools. School is one place to develop teacher professionalism in activities, with various activities carried out by the principal in order to establish the effectiveness of teachers in work. The quality of education is one of the benchmarks that determine the dignity of a nation. The teacher has a vital role in the process of learning and teaching, this can be seen from the tasks and functions during school, namely transferring knowledge to students. This proves the teacher's job performance is one of the determining factors of the quality of Education in an Educational Institution.

The development of a country, seen from the progress of the construction of the city. Advanced city development can only be achieved if human development is also advanced and intelligent. To develop human beings into intelligent human beings, of course, the presence of high-quality, literate people from illiteracy is needed. Smart citizens of a city become one of the parameters of HDI (human development index). Higher education needs to be fought because for a smart city must compete both nationally and globally. High competition enables cities and countries to be ranked equal to developed countries. In this context, South Tangerang, as a new city was born in 2007 from the expansion of the City of Tangerang. The birth of South Tangerang was based on the Tangerang Regent Decree Number 130 / Kep.149-Huk / 2007 dated February 19, 2007 concerning the Approval of the Establishment of the City of South Tangerang.

In implementing regional autonomy, South Tangerang City as a buffer zone of the Jakarta Capital City, South Tangerang has carried out various efforts to improve economic capacity, prepare government facilities and infrastructure, empower and enhance human resources, 
and manage natural resources in accordance with laws and regulations. The main focus of the South Tangerang Government in education of its citizens is that every citizen can access education at least 12 years. The ability of education to be creative and innovative human beings must be in the coaching program of the South Tangerang Government. In measuring the quality of education in Indonesia, the National Examination commonly abbreviated as UN is a national evaluation system for basic and secondary education and the quality of education between regions carried out by the Education Assessment Center, Ministry of National Education in Indonesia based on Law Number 20 of 2003. Based on the results of the National Examination for Junior High
School Level which was announced on May 25, 2018, Some Junior High Schools in South Tangerang City got the highest score with an average of 61.53 from 4 subjects namely Indonesian, English, Mathematics and Natual Sciences, (Media, 2018). From the data collected below is a recapitulation of data from the results of the SMP National Examination in South Tangerang City from 2013-2018, there are interesting things from the data below, namely the results of UN from year to year experienced a downward trend.

Tabel 1. List of SMP National Exam Results in South Tangerang City 2013 - 2018

\begin{tabular}{|c|c|c|c|c|c|c|}
\hline \multirow{2}{*}{ NO. } & \multirow{2}{*}{$\begin{array}{l}\text { SCHOOL } \\
\text { YEAR }\end{array}$} & \multirow{2}{*}{$\begin{array}{l}\text { Result } \\
\text { UN/UNBK }\end{array}$} & \multicolumn{4}{|l|}{ Subjects } \\
\hline & & & Indonesian & English & Math & Natural Sciences \\
\hline \multirow{2}{*}{1} & \multirow{2}{*}{$2013-2014$} & Avarage & 7,75 & 7,08 & 6,84 & 6,83 \\
\hline & & Category & $A$ & B & B & B \\
\hline \multirow{2}{*}{2} & \multirow{2}{*}{$2014-2015$} & Avarage & 73,01 & 65,42 & 55,88 & 57,35 \\
\hline & & Category & B & C & C & C \\
\hline \multirow{2}{*}{3} & \multirow{2}{*}{$2015-2016$} & Avarage & 74,33 & 62,13 & 48,68 & 54,87 \\
\hline & & Category & $\mathrm{B}$ & C & $\mathrm{D}$ & $\mathrm{D}$ \\
\hline \multirow{2}{*}{4} & \multirow{2}{*}{$2016-2017$} & Avarage & 68,65 & 55,57 & 51,31 & 52,73 \\
\hline & & Category & C & C & D & D \\
\hline \multirow{2}{*}{5} & \multirow{2}{*}{$2017-2018$} & Avarage & 72,26 & 60,51 & 46,83 & 51,71 \\
\hline & & Category & B & C & D & D \\
\hline
\end{tabular}

Based on these data, can reflect the ability of students to be independent has not been realized optimally, so the initiative of students to start something is not too often found. The root cause of all this is certainly very much but the main accusation is mostly directed at the teacher. The teacher is the spearhead in the field who meets programmatically students. In addition, the well-being of teachers, who are aware of being a pillar of the quality of job performance provided by teachers, has also begun to be noticed, even on a very small scale (Schyns, Van Veldhoven, \& Wood, 2009). Job performance is the result of work in quality and quantity achieved by an employee in carrying out his duties in accordance with the responsibilities given to him (Colquitt, LePine, \& Wesson, 2015). High and low job performance is closely related to the reward system applied by the Institution or organization where they work (Luthans, 2012).

Teacher job performance is the teacher's perception of teacher work job performance related to the quality of work, responsibility, honesty, cooperation and initiative. This is because the purpose of working the teacher is much influenced by whether or not the minimum needs of the life of the teacher and his family are met. Thus the impact is increasing the teacher's full attention to the profession and work (Xu et al., 2015).

The task of the principal as a manager is to carry out management functions in the form of planning, organizing, implementing and evaluating job performance (Mullins, 2010; Robbins \& Coulter, 2016; Williams, 2011). To prepare teacher job performance plans, the principal involves all elements of school personnel. The principal as a leader is one component of education that has an influence in improving teacher job performance. The leadership's concern for the teacher's learning culture is very weak. This condition is seen from the tendency of the attitude of teachers who do not care about the culture of learning in school. There are some teachers who only provide notes or assignments to students when teaching in class, the teaching and learning process tends to be monotonous, this means that the tendency needs to be analyzed and solutions are sought so that the teacher has good job performance. 
Based on the description and data found in the field, current teacher job performance still needs to be improved with several approaches such as supportive leadership, learning culture, responsibility, emotional intelligence, job satisfaction, environment and reward.

\section{LITERATURE REVIEW}

\subsection{Job Job Performance}

Teachers who have a role in the learning process are not only educators, but also as instructors and trainers. Every individual who has responsibility is expected to be able to show satisfactory job performance and make a maximum contribution to the institution or organization. Yang, Cheng-Liang Hwang, Mark defines job performance as follows, "job job performance measures are individual against his or her goal, with an emphasis on whether outcomes match the expected goal (Yang \& Hwang, 2014a). Job performance measures the individual's achievement of its objectives, with emphasis on whether the results match the expected goals. Job performance is the result of work in quality and quantity achieved by an employee in carrying out its functions in accordance with the responsibilities given to him. Jason A. Colquitt et.al defines job performance as follows, "job job performance is defined as employee behavior that contributes, either positively or negatively, to organizational goal accomplishment (Colquitt et al., 2015).

Job performance can be formally defined as a set of values from a set of employee behaviors that contribute both positively and negatively to the fulfillment of organizational goals. Steve M.Jex defines job performance as follows, "job job performance is a deceptively simple term. At the most general level, it can be defined as all the behaviors of employees engaging in while at work "(Jex \& Britt, 2008). Job performance can be defined simply as all behaviors performed by employees while at work. Job performance appraisal is basically a key factor in developing an organization effectively and efficiently, because of better policies or programs, for human resources in the organization. John M. Ivancevich et al. Defines job performance as follows, "job job performance of employee work related behavior designed to achieve organizational goals (Ivancevich \& Konopaske, 2014). Job performance is a set of behaviors related to employee work designed to achieve organizational goals.

While Chuck Williams defines job performance as follows, "job job performance is how someone performs the requirements of the job (Williams, 2011). Job performance is how well someone meets the requirements of a job. Job performance is the result or level of success of a person as a whole over a certain period of time in carrying out tasks compared to various possibilities, such as standard work results, targets or targets that have been determined in advance. Nick Forster Job performance is defined as follows, "job job performance is defined as the successful completion of a task, an action or process at work (Forster, 2005). Job performance can be defined as success in completing a task, activity or process in a job. James L. Gibson, et.al defines job performance as follows, "job job performance is the outcome of jobs that relate to the purposes of the organization such as quality, efficiency and other criteria of effectiveness" (Gibson, Ivancevich, Donnelly, Jr., \& Konopaske, 2012). Job performance is the end result of a job related to organizational goals such as quality, efficiency and other criteria of job performance. Job performance is the result of evaluation of the work performed compared to the criteria that have been set.

Based on ther description above can be synthesized job performance is a work activity that is displayed by someone in carrying out work functions in a certain period of time that contributes to the achievement of organizational goals with indicators:1) employee behavior, 2) actions at work, 3) work procedures and 4) results work.

\subsection{Supportive Leadership}

Today's globalization of education is expected to be more modern and professional so as to be able to realize its role effectively with excellence in leadership, staff, teaching and learning processes, staff development, curriculum, goals and expectations, school climate, self assessment, communication, and parent / community involvement. Leadership is an activity to influence people to be directed towards achieving organizational goals. Leadership style according to Path-Goal Theory (Luthans, 2012). Directive Leadership is a leadership style that has a positive relationship with subordinate satisfaction and expectations. Bosses often give special orders or special (autocracy). (1). Participatory Leadership is a leadership style that asks and uses subordinate suggestions in order to make decisions; (2) Supportive Leadership, which is a leadership style that is always willing to explain all problems in subordinates, easy to approach and satisfy the employees. This type of leader usually shows an attitude that is friendly and shows concern for it, considering the needs of the subordinates, showing their concern for creating prosperity and being friendly to the work environment. This includes increasing motivation from oneself and making work more interesting. This style is very effective when facing work that is difficult, stressful, boring or dangerous. This behavior is very necessary in situations where the task or physical or psychological relationship is not good. (Luthans, 2012).

McGurk explained supportive leadership as follows, "supportive leadership is the extent to which, leaders provide emotional, informational, or instrumental help to followers through demonstrating care and concern and providing useful job performance feedback, information, and advice. (McGurk et al., 2014). Supportive leadership is the extent to which leaders provide assistance emotionally, various information to their followers by showing concern, attention and providing feedback with the aim of improving the job performance of their 
followers. Furthermore, according to House in Robbins, supportive leadership, namely leadership that is always willing to explain all problems in subordinates, is easily approachable and satisfies the employees. (Robbins \& Coulter, 2016). Bruce Avolio and Bass define supportive leadership as follows, "defined supportive leadership in terms of general support for the efforts of followers and behavior on the part of the leader which indicates that he or she respects his or her followers and is concerned with followers feeling and needs (CJ Newton \& Maierhofer, 2005). Supportive leadership is a leader who supports his followers in daily activities by respecting, caring for the feelings of employees and paying attention to the needs of his followers both materially and non-materially. The same thing expressed by House, Rafferty and Griffin defines supportive leadership as follows, "defined supportive leadership as behavior that expresses concern for followers and their individual needs. It is this definition that has been adopted in this study (C. J. Newton \& Maierhofer, 2005). Supportive leadership is the behavior of a leader who supports his employees by paying attention to the needs of employees at work.

This definition was extended by Oldham an Cummings, "depict supportive leadership as all behavioral managers, which support their job followers (Elsaied, 2018). Supportive leadership is the behavior of a leader in managing the organization he leads to support his work in working in various ways including paying attention to all the needs needed at work, paying attention to the conditions of the employees at work. According to Blau in developing the theory of supportive social exchange of things that an organization needs, here is an explanation "We argue that supportive leadership may provide added impulse to team members within cohesive teams to take specific actions, and therefore, to enhance their ability to share and combine exploratory and exploitative learning activities (Jansen, Kostopoulos, Mihalache, \& Papalexandris, 2016). Supportive leadership can provide additional impetus to employees to take certain actions in order to improve their abilities in various ways with colleagues by combining exploratory and exploitative learning processes.

Different things expressed by Newton and Maierhofer define supportive leadership as follows, "supportive leadership is a distinguished from transformational leadership, which influences subordinates by broadening and elevating followers' goals and providing them with confidence to perform beyond expectations specified in the implicit or explicit exchange agreement (CJ Newton \& Maierhofer, 2005). Supportive leadership is different from transformational leadership, leadership influences the followers widely by helping to increase the confidence of employees to work better, uniting perceptions of the common goal of improving organizational job performance.

Based on the explanation above, it can be synthesized that supportive leadership is the concern of a leader to his followers which is manifested in the form of attention related to the work process with indicators: 1) attention to employee needs 2) creating a conducive work environment, 3) facilitating employee needs in improving competence.

\subsection{Learning Culture}

Regarding the development of the environment and the culture in which education is located, the quality of education is oriented towards debriefing students to be able to change at any time, adjusting to the development of the environment and culture. Therefore the organization is expected to become a learning organization that continues to adjust to the changes that exist today as revealed by Yoon et. al about learning organizations as follows, "learning organization is a supportive environmental factor, whereas organizational learning is a collaborative process of problem solving and detection and correction of errors. Organizational learning takes place when members collaboratively and diligently correct past errors and shape future goals, rules, plans, and actions ", (Yoon, Song, Lim, \& Joo, 2010).

Learning organization is the process of an organization adjusting to the changes it faces such as preparing an environment that supports learning, whereas organizational learning is a collaborative process of solving, detecting and repairing a problem. Eid and Nuhu further explained what learning organizations are, "learning organizations have been defined as ideal structure and culture that continuously acquires, processes, and disseminates knowledge about markets, products, technologies, and business processes (Eid \& Nuhu, 2011). Learning organizations are a structure, an ideal culture that continuously acquires, processes, and disseminates knowledge about conditions in the field, products, technology, and business processes. Butler and Dickinson define learning culture as follows, "learning culture as structure, process and climate of the norm and channel teacher, staff and student induction of successful teaching and learning (Butler \& Dickson, 1987). Learning culture is a structure, process and climate of values and norms that channel teachers, staff and students who have strategies in teaching and learning so that learning objectives are achieved.

Different things expressed by Johnston and Hawke define learning culture as follows, "learning learning culture as existence of a set of attitudes, values, and practices within an organization which supports and encourages a continuing process of learning for the organization and/or its members. (Mukhopadhyay et al., 2013). Learning culture as the existence of a set of attitudes, values, and practices in organizations that support and encourage a continuous learning process for the organization or its members. Watkins and Marsick define learning culture as follows, "learning organization culture utilizes a dynamic team-based approach along with collaborative questioning and communication to facilitate the process of organizational learning (Yoon, Song, Lim, \& Joo, 2010b). Organizational learning culture 
uses a dynamic team approach along with questions and collaborative communication to facilitate the organizational learning process.

Heo et.al defines learning culture as follows, "learning culture is an important component to understand the educational system in a country and it is a cultural context of that country. Learning culture is a set of shared beliefs, favorable to learning values and attitudes (Heo, Leppisaari, \& Lee, 2018b). Learning culture is an important component to understanding the education system in a country and can be influenced by the country's social and cultural context. Learning culture is defined as a set of beliefs, values, and shared attitudes that are beneficial for learning. Mukhopadhyay explained the learning culture as follows, "a learning culture is said to exist in environment where teamwork, collaboration, creativity, and knowledge processes exist that have a collective meaning and value. For an organization to improve its job performance, it requires a learning culture (Mukhopadhyay et al., 2013). Learning culture is said to exist in an environment where teamwork, collaboration, creativity, and knowledge processes exist that have collective meaning and value.

Based on some concept descriptions presented above, it can be synthesized that learning culture is a series of activities in carrying out learning tasks, making learning a habit, and making learning a hobby and pleasure, so motivation to learn arises from within itself with indicators, 1) attitude, 2) Norms, 3) values and 4) habits.

\subsection{Responsibility}

Cornock quoted by S.K. McGrath, S.J. Whitty defines responsibility as follows, "responsibility means to be responsible for act one undertakes, while accountability simply means to be called to account". This definition of responsibility is not fully adequate, that is, the definition of responsibility, but not in conflict with the definition derived from this paper. The definition is not compatible with the tentative definition, (McGrath \& Whitty, 2018). Responsibility means being responsible for the actions taken, while accountability only means being called into account. The definition of accountability does not include positive meaning, that is, why someone will be called to be responsible, but still in accordance with the tentative definition. Mullins said that, "the responsibility of accepting possible reprimand from the manager for involvement and obligation by the subordinate to perform certain duties and to have in unsatisfactory job performance (Mullins, 2010).

The responsibility of receiving a possible reprimand from the manager for involving and obligations by subordinates to perform certain tasks makes certain decisions and has unsatisfactory job performance. Ricard L. The draft defines responsibility as follows, "responsibility is the flip side of the authority coin, responsibility is the duty to perform the task or activity as assigned (Daft, 2014). Responsibility is the other side of coin authority, responsibility is the obligation to perform tasks or activities as assigned. Stephen Robbins and Mary Coulter define responsibility as follows: "responsibility is the obligation to perform any assigned duties (Robbins \& Coulter, 2016). Responsibility is an obligation to carry out tasks well.

Ricky W. Griffin and Gregory Moorhead define responsibility as follows, "responsibility is an obligation to do something with the expectation that some act or out put will result" (Griffin \& Moorhead, 2014). Responsibility is the obligation to do something in the hope that some action or action will result. A person can be called a responsible human if he is able to make choices and make decisions on the basis of certain values and norms, both those originating from within him and those originating from his social environment. John W. Slocum, Jr. and Don Hellrigel said, "Responsibility taking responsibility for personal choices admits mistakes and failures embracing responsibility for serving others (Hellriegel \& Slocum, 2011).The responsibility of taking responsibility for personal choices recognizes mistakes and failures that include responsibility for serving others. Responsibility always revolves around awareness to do, willingness to do, and ability to do. Crawford said, "responsibility is a psychological phenomenon in which people are less likely to take action or a sense of responsibility in the presence of a large group of people. Essentiality in a large group of people, people may feel that individual responsibility for intervention is lessened because it is shared by all of the onlookers (Cabanis-Brewin, Barrett, L.West, Wourms, \& S. Pennypacker, 2004). So according to Crawford, responsibility is a psychological phenomenon where people tend to take action or responsibility before a large group of people. The responsibility of each individual is reduced because it is shared with everyone involved in it.

Jason A. Colquiit, Jeffery A. Lepine and Michael J. Wesson, said, "Responsibility for outcomes that captures the degree to which employees feel that they are a key driver of the quality of the unit's work" (Colquitt et al., 2015). Responsibility for results captures the rate at which employees feel they are the main drivers of the quality of the work of the unit. The presence of teachers in the learning process as a means of inheriting values and norms still plays a very important role. Laurie J. Mullins defines responsibility as follows, "responsibility involves and obligation by the subordinates to certain duties and decisions to accept possible reprimand from the manager for unsatisfactory job performance (Mullins, 2010). Responsibility relates to the obligation of members to perform their duties properly so as not to get a reprimand from the manager for unsatisfactory job performance.

Based on the explanation stated above, it can be synthesized that responsibility is a manifestation of accountability for one's decisions and actions in working with indicators: 1) performing tasks well, 2) being trustworthy and 3) and being reliable. 


\section{Research Hypotheses}

1. Supportive leadership has a positive direct effect on job performance.

2. Learning culture has a direct positive effect on job performance.

3. Responsibility has a direct positive effect on job performance.

4. Supportive leadership has a direct, direct effect on responsibility.

5. Culture of learning has a positive direct effect on responsibility.

6. Supportive leadership has a positive direct effect on learning culture.

\section{METHODS}

This quantitative research uses a survey method through the Path Analysis approach. The instrument used in all variables in the form of questionnaires. Before being used in the study, an instrument trial was conducted to test the validation and reliability of each instrument so that it could be used in the study. The study was conducted on
213 teachers in the Public Middle School in the City of South Tangerang. The number of teachers is 213 teachers and sampling using the Slovin formula. Samples are obtained by simple random methods from the population. The data in this study were collected using instruments in the form of questionnaires which included job performance questionnaires, supportive leadership, learning culture and responsibility, which had gone through the stages of empirical validation through instrument testing. Furthermore, the calculation of reliability is carried out on a valid instrument item that shows the feasibility of the instrument to be used in the study.

The research data analysis technique was analyzed using descriptive analysis and inferential analysis with a path analysis approach. Descriptive analysis is done by calculating the average, median, mode, variance, and standard deviation values. The data characters of each variable are displayed in the frequency distribution table and histogram. Inferential analysis is preceded by an analysis of the requirements test, consisting of the estimated error normality test, significance test, and linearity test. The relationship between each variable in this study is presented in the form of constellations as follows:

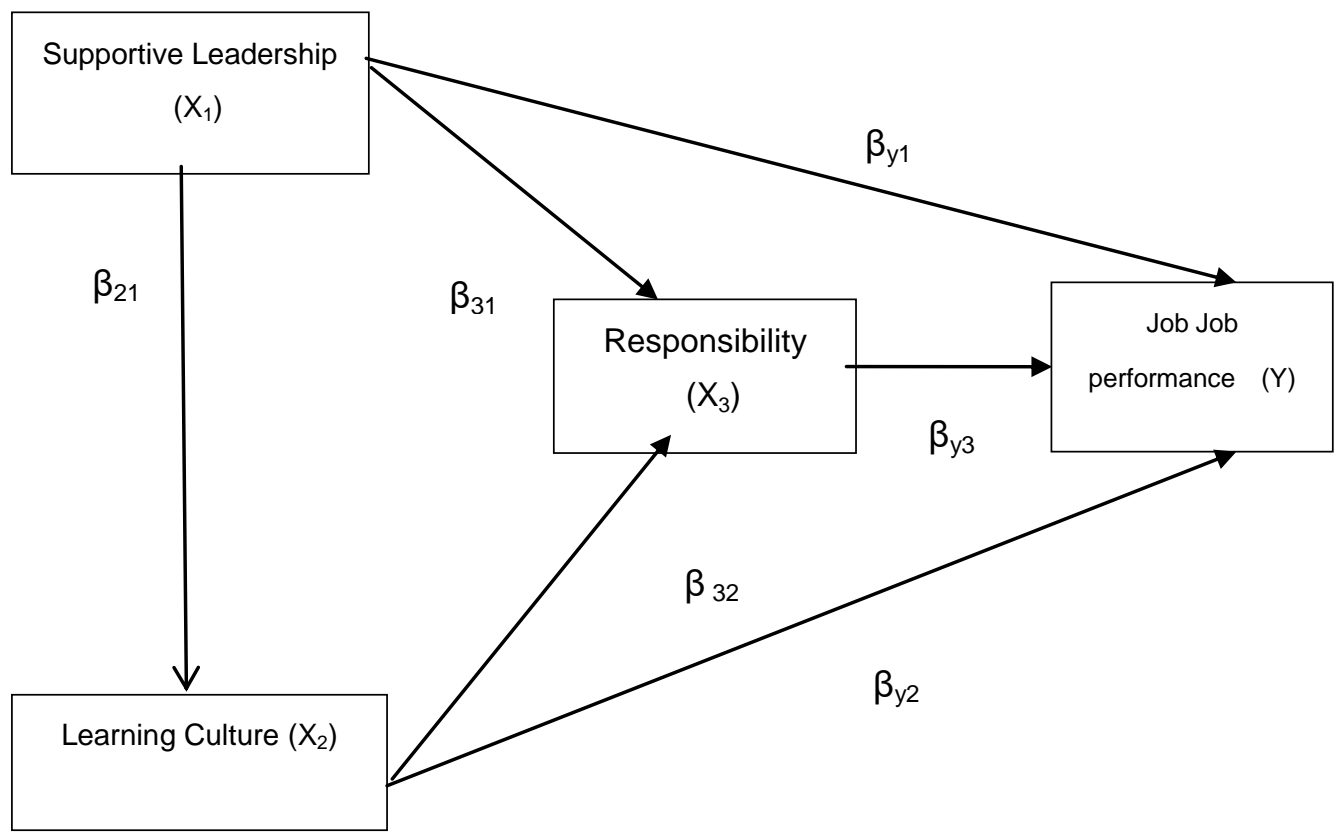

Caption :

$\mathrm{X} 1$ : Supportive leadership

X2: Learning Culture

X3: Responsibility

$\mathrm{Y}$ : Job performance

\section{RESULTS AND DISCUSSION}

Data measurement of this research was carried out on endogenous variables and exogenous variables. Endogenous variables are variables that are influenced by variables whose variations are explained by exogenous variables and other endogenous variables in the system. This research which is an endogenous variable is job performance $(\mathrm{Y})$. The exogenous variables or influencing variables are variables whose variations are assumed to 
occur not because of the reasons in the model, exogenous variables in this study are supportive leadership (X1), learning culture (X2) and responsibility (X3). A summary of research data on endogenous and exogenous variables is presented in table 2 .

Table 2. Variable Data Summary of Supportive Leadership, Learning Culture Responsibility and Job performance

\begin{tabular}{|c|c|c|c|c|}
\hline \multirow[t]{2}{*}{ Information } & \multicolumn{4}{|c|}{ Variable } \\
\hline & Supportive Leadership & Learning Culture & Responsibility & Job performance \\
\hline Samples (N) & 213 & 213 & 213 & 213 \\
\hline Mean & 124,869 & 127,282 & 130,300 & 132,765 \\
\hline Median & 125 & 127 & 130 & 133 \\
\hline Modus & 124 & 128 & 130 & 135 \\
\hline Std Deviasi & 4,349 & 4,379 & 4,395 & 4,536 \\
\hline Varians & 18,917 & 19,175 & 19,315 & 20,577 \\
\hline Range & 18 & 17 & 17 & 17 \\
\hline Maksimum & 135 & 135 & 139 & 141 \\
\hline Minimum & 117 & 119 & 122 & 124 \\
\hline Sum & 26597 & 27111 & 27754 & 28279 \\
\hline
\end{tabular}

It can be explained that the score of the job performance variable is above average, it can be stated that the job performance performed by PNS teachers is very good. Job performance consists of 4 indicators, namely employee behavior, work actions, work procedures, and work results. Job performance variable data per indicator can be presented in the data Table 3 .

Table 3. Job Performance Variable Data Distribution Per Indicator

\begin{tabular}{llcccc}
\hline No & Indicator & Number of items & Total Score & Avarage Score & Persentase \\
\hline 1 & Employee Behavior & 11 & 9568 & 4,084 & 34,375 \\
\hline 2 & Action at work & 7 & 6105 & 4,095 & 21,875 \\
\hline 3 & Work procedure & 8 & 7154 & 4,198 & 25,000 \\
\hline 4 & Work Result & 6 & 5452 & 4,266 & 18,750 \\
\hline & Total & $\mathbf{3 2}$ & $\mathbf{2 8 2 7 9}$ & & $\mathbf{1 0 0}$ \\
\hline
\end{tabular}

Based on the Table 3 above, it can be seen that the indicator that has the highest average score is a work outcome indicator of 4,266 and has a contribution of $18,750 \%$. This means that there are $18,750 \%$ contributions from work outcome indicators. This shows that work outcome indicators are indicators that can encourage improvement in teacher job performance. The indicator that has the lowest average score is on the employee behavior indicator, which is 4,084, while it has a contribution of $34.375 \%$. This means that there are $34.375 \%$ of the contribution of these indicators to improving teacher job performance. In this case the indicator of employee behavior can be a concern for the principal and the teacher itself. For more details the data per indicator for job performance variables can be presented in the form of the following diagram.

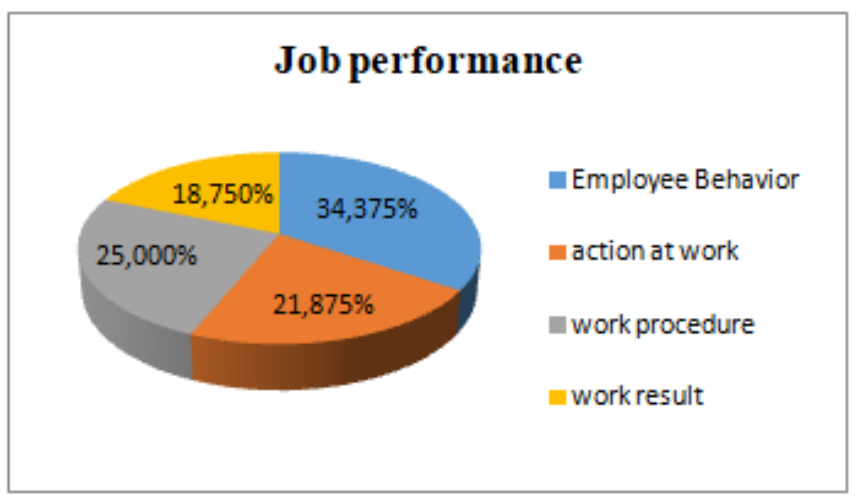

Fig 1. Percentage Scores Per Indicator Diagram for Job Performance Variable 


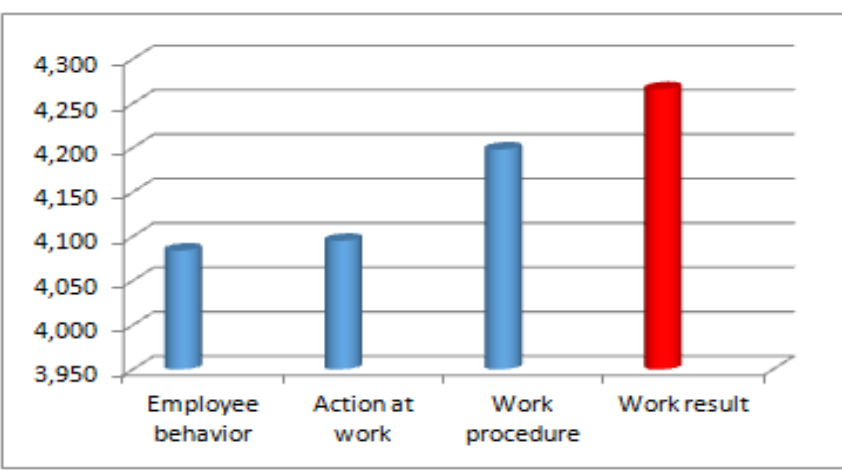

Fig 2. Average Score Diagram Per Indicator for Job performance variable frequency distribution can be explained that the score of the supportive leadership variable is above the average, so it can be stated that the supportive leadership that is carried out by the headmaster of state junior high schools is very good. Supportive leadership variables consisting of 3 indicators namely attention to the needs of employees, creating a conducive work environment, and facilitating the needs of employees in improving their competence. Supportive leadership variable data per indicator can be presented in the data below:

Table 4. Data on Variable Distribution of Supportive Leadership Per Indicator

\begin{tabular}{rlcccc}
\hline No & Indicator & Number of items & Total Score & Avarage Score & Persentase \\
\hline 1 & Attention to employee needs & 10 & 8751 & 4,108 & 33,333 \\
\hline 2 & Creating a conducive work environment & 10 & 8826 & 4,144 & 33,333 \\
\hline 3 & $\begin{array}{l}\text { Facilitating employee needs in improving their } \\
\text { competence }\end{array}$ & 10 & 9020 & 4,235 & 33,333 \\
\hline & Total & $\mathbf{3 0}$ & $\mathbf{2 6 5 9 7}$ & 100
\end{tabular}

Based on ther Table 4 above, it can be seen that the indicator that has the highest average score is an indicator facilitating the needs of employees in increasing their competence by 4,235 and contributing 33,333\%. This means that there are $33,333 \%$ contributions from indicators facilitating the needs of employees in improving their competence. Indicators that have the lowest average score are found in the indicator of attention to the needs of employees, which is 4,108 , while having a contribution of $33,333 \%$ This means that there are $33,333 \%$ of the contribution of these indicators to improving supportive leadership. In this case the attention indicator for the needs of these employees can be of concern to the principal. For more details, the data per indicator for supportive leadership variables can be presented in the form of the following diagram:

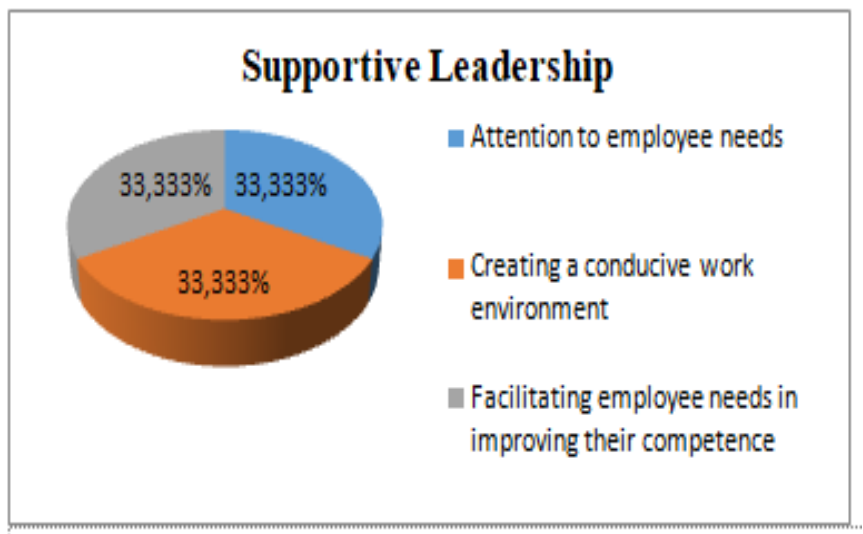

Fig. 3. Percentage Scores Per Indicator Diagram for Variable for Supportive Leadership
The results of the study imply that in general there are six positive direct influences for teachers of Public Middle Schools in the City of South Tangerang: (1) supportive leadership for job performance, (2) learning culture for job performance, (3) job performance responsibility, (4) supportive leadership towards responsibility, (5) learning culture towards responsibility, and (6) supportive leadership towards learning culture.

\subsection{The Effect of Supportive Leadership on Job}

\section{Performance}

To prove supportive leadership has a direct positive effect on job performance, the statistical hypothesis is: $\mathrm{H}_{0}$ : $B_{\mathrm{y} 1} \leq$ $0, \mathrm{H}_{1}: B_{\mathrm{y} 1}>0$. The calculation results of the effect of supportive leadership work on job performance, obtained path coefficient of 0.277 and tcount of this path coefficient of 3.542 , $\mathrm{t}_{\text {count }}(3,542)>\mathrm{t}_{\text {table }}(2,344)$ at $\mathrm{\alpha}=0,01$, then $\mathrm{H}_{0}$ is rejected. It can be concluded that there is a positive direct effect of supportive leadership on job performance. That is, increasing supportive leadership will result in improved job performance.

The results showed that supportive leadership had an effect on job performance, it could be interpreted that the supportive leadership possessed by teachers, led to an increase in the job performance of teachers in the Public Middle School in South Tangerang City. Based on this empirical evidence, it is said that these findings indicate supportive leadership is one of the variables that directly affects the job performance variable. Supportive leadership will have an effect on increasing teacher job performance. 


\subsection{Effect of Learning Culture on Job Performance}

To prove the learning culture has a positive direct effect on job performance, the statistical hypothesis is: H0: By $2 \leq 0, \mathrm{H} 1$ : By $2>0$. The results of the calculation of the effect of learning culture on job performance, path coefficients are 0.210 and tcount of this path coefficient is 2.801 , tcount $(2,801)>$ ttable $(2,344)$ at $\alpha=0.01$, then $\mathrm{H} 0$ is rejected. Thus it is concluded that there is a positive direct effect of learning culture on job performance.

The results of the study showed that the learning culture had an effect on job performance, it could be interpreted that a good learning culture would lead to an increase in the job performance of teachers in the Public Middle School in South Tangerang City. Based on this empirical evidence, it is said that this finding shows that learning culture is one of the variables that directly influences the job performance variable. A good learning culture will affect the increase in job performance of the teacher.

\subsection{Effect of Responsibility on Job Performance}

To prove responsibility has a positive direct effect on job performance, the statistical hypothesis is: $\mathrm{H}_{0}$ : $\mathrm{B}_{\mathrm{y} 3} \leq 0, \mathrm{H}_{1}$ : $B_{\mathrm{y} 3}>0$. The results of the calculation of the effect of responsibility for job performance, path coefficient is 0.280 and $t_{\text {count }}$ of this path coefficient is $4.549, \mathrm{t}_{\text {count }}(4,549)>$ table $(2,344)$ at $\mathrm{a}=0.01$, then $\mathrm{H}_{0}$ is rejected. Thus it is concluded that there is a positive direct effect of responsibility for job performance.

The results of the study show that responsibility influences job performance, meaning that the increase in teacher responsibility will lead to an increase in the job performance of teachers in the Public Middle School in South Tangerang City. Based on this empirical evidence, it is said that these findings indicate responsibility is one of the variables that directly affects the job performance variable. high responsibility will affect the increase in job performance of the teacher.

\subsection{Effect Supportive Leadership om Responsibility}

To prove supportive leadership has a direct positive effect on responsibility, the statistical hypothesis is: $\mathrm{H} 0: B 31 \leq 0$, $\mathrm{H} 1$ : $B 31>0$. The results of the calculation of supportive leadership influence on responsibility, path coefficients are 0.385 and the tcount of this path coefficient is 4.609 , tcount $(4,609)>$ ttable $(2,344)$ at $\alpha=0,01$, then $\mathrm{HO}$ is rejected. Thus it is concluded that there is a positive direct effect of supportive leadership on responsibility.

Appropriate supportive leadership will have the effect of increasing responsibility for the teacher. The results of the study show that supportive leadership influences responsibility, meaning that good supportive leadership possessed by the teacher will lead to an increase in the responsibility of teachers in the Public Middle School in South Tangerang City. Based on this empirical evidence, it is said that these findings indicate supportive leadership is one of the variables that directly influences the variable responsibility.

\subsection{Effect Learning Culture on Responsibility}

To prove the learning culture has a positive direct effect on responsibility, the statistical hypothesis is: H0: $632 \leq 0$, $\mathrm{H} 1: \mathrm{B} 32>0$. The results of the calculation of the influence of learning culture on responsibility, path coefficients are 0.144 and the tcount of this path coefficient is 1.726 , tcount $(1,726)<$ ttable $(1,652)$ at $\alpha=0,05$, then $\mathrm{H} 0$ is rejected. Thus it is concluded that there is a positive direct effect of learning culture on responsibility.

The results of the study show that the learning culture influences responsibility, meaning that a good learning culture will lead to an increase in the responsibility of teachers in the State Middle School in South Tangerang City. Based on this empirical evidence, it is said that this finding shows that learning culture is one of the variables that directly influences the variable responsibility. A good learning culture will affect the increase of responsibility to the teacher.

\subsection{Effect Supportive Leadership on Learning Culture}

To prove supportive leadership has a positive direct effect on learning culture, the statistical hypothesis is: H0: $821 \leq$ $0, \mathrm{H} 1: \mathrm{B} 21>0$. The results of calculation of the influence of supportive leadership on learning culture, path coefficients are 0.697 and the tcount of this path coefficient is 14.116 , tcount $(14.116)>$ ttable $(2,344)$ at $\alpha=$ 0.01 , then H0 is rejected. Thus it was concluded that there was a positive direct effect of supportive leadership on the learning culture.

The results of the study showed that supportive leadership had an effect on the learning culture, meaning that appropriate supportive leadership would lead to an increase in the culture of teacher learning at the State Middle School in South Tangerang City. Based on this empirical evidence, it is said that this finding shows that supportive leadership is one of the variables that directly influences the learning culture variable.

\section{CONCLUSION}

Based on the results of testing hypotheses and discussing the results of the research presented in the previous chapter, through research conducted on teachers SMPN at the South Tangerang the following conclusions were obtained: (1) supportive leadership has a positive direct effect on teacher job performance in South Tangerang. This means that improved supportive leadership will lead to high job performance improvements; (2) learning culture has a positive direct effect on teacher job performance in South Tangerang. This means that a high increase in learning culture will lead to high job performance improvements; (3) responsibility has a positive direct effect on teacher job performance in South Tangerang. This means that a high increase in 
responsibility will lead to high job performance improvements; (4) supportive leadership has a positive direct effect on teacher responsibilities in the South Tangerang. This means that good supportive leadership will lead to a high increase in responsibility; (5) learning culture has a positive direct effect on teacher responsibilities in South Tangerang. This means that an increase in a high learning culture will lead to a high increase in responsibility; (6) supportive leadership has a positive direct effect on the culture of teacher learning in South Tangerang. This means that good supportive leadership will lead to a high increase in learning culture.

Based on the research findings above, it can be stated that job performance can be influenced by the variables of supportive leadership, learning culture, and responsibility. However, other variables still need to be considered in further research related to job performance variables. Based on the conclusions of this study indicate that in improving the job performance of teachers can be done by improving supportive leadership, learning culture, and increasing responsibility in the teacher.

\section{REFERENCES}

Butler, J. A., \& Dickson, K. M. (1987). Improving School Culture. School Improvement Research Series, 4.

Colquitt, J., LePine, J. A., \& Wesson, M. J. (2015). Organizational behavior: improving job performance and commitment in the workplace (Fourth edition). New York, NY: McGraw-Hill Education.

Daft, R. L. (2014). New Era of Management (9th ed.). South-Western Cengage Learning.

Eid, M., \& Nuhu, N. A. (2011). Impact of learning culture and information technology use on knowledge sharing of Saudi students. Knowledge Management Research and Practice, 9(1), 48-57. https://doi.org/10.1057/kmrp.2010.25

Gibson, J. L., Ivancevich, J. M., Donnelly, Jr, J. H., \& Konopaske, R. (2012). Organizations: Behavior, Structure, Processes. McGraw-Hill Irwin, 642.

Griffin, R. W., \& Moorhead, G. (2014). Organizational behavior: managing people and organizations (11th Edition). Australia: South-Western/Cengage Learning.

Hellriegel, D., \& Slocum, J. W. (2011). Organizational behavior (13th ed). Mason, Ohio: South-Western Cengage Learning.

Heo, H., Leppisaari, I., \& Lee, O. (2018a). Exploring learning culture in Finnish and South Korean classrooms. Journal of Educational Research, 111(4), 459-472.

https://doi.org/10.1080/00220671.2017.1297924

Ivancevich, J. M., \& Konopaske, R. (2014). Organizational behavior and management (Tenth Edition). New York: McGraw-Hill Companies, Inc.
Luthans, F. (2012). Organizational behavior an evidence-based approach 12th edition.

Mc Gurk, D., Sinclair, R. R., Thomas, J. L., Merrill, J. C., Bliese, P. D., \& Castro, C. A. (2014). Destructive and Supportive Leadership in Extremis: Relationships With Post-Traumatic Stress During Combat Deployments. Military Behavioral Health, 2(3), 240-256. https://doi.org/10.1080/21635781.2014.963765

Media, K. C. (2018, June 7). 5 SMP Negeri Kota Tangsel dengan Hasil UN Tertinggi. Retrieved December 1, 2018 , from https://edukasi.kompas.com/read/2018/06/07/180104 01/5-smp-negeri-kota-tangsel-dengan-hasil-un-tertin ggi

Mukhopadhyay, C., Akhilesh, K. B., Srinivasan, R., Gurtoo, A., Ramachandran, P., Iyer, P. P., ... Bala Subrahmanya, M. H. (Eds.). (2013). Driving the Economy through Innovation and Entrepreneurship. India: Springer India. https://doi.org/10.1007/978-81-322-0746-7

Mullins, L. J. (2010). Management and organisational behaviour (9. ed). Harlow: Financial Times Prentice Hall.

Newton, C. J., \& Maierhofer, N. I. (2005). Supportive Leadership and Well-being: The Role of Team Value Congruence, 6.

Robbins, S. P., \& Coulter, M. K. (2016). Management (13th edition). Boston: Pearson.

Schyns, B., van Veldhoven, M., \& Wood, S. (2009). Organizational climate, relative psychological climate and job satisfaction: The example of supportive leadership climate. Leadership \& Organization Development Journal, 30(7), 649-663. https://doi.org/10.1108/01437730910991664

Williams, C. (2011). Management (6th ed.). United State of America: South-Western Cengage Learning.

Xu, Z., Özek, U., \& Hansen, M. (2015). Teacher Job performance Trajectories in High- and Lower-Poverty Schools. Educational Evaluation and Policy Analysis, 37(4), 458-477. https://doi.org/10.3102/0162373714561513

Yang, C.-L., \& Hwang, M. (2014a). Personality traits and simultaneous reciprocal influences between job job performance and job satisfaction. Chinese Management Studies, 8(1), 6-26. https://doi.org/10.1108/CMS-09-2011-0079

Yoon, S. W., Song, J. H., Lim, D. H., \& Joo, B. K. (2010a). Structural determinants of team job performance: The mutual influences of learning culture, creativity, and knowledge. Human Resource Development International, 13(3), 249-264. https://doi.org/10.1080/13678868.2010.483815 